
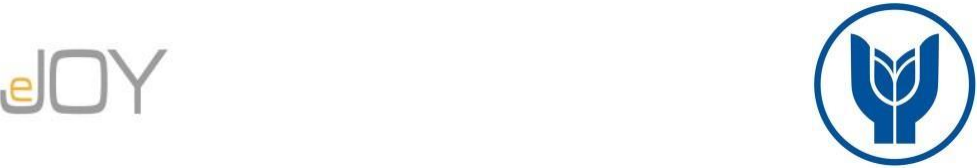

Asarkaya, C., Ozer Torgaloz, A. / Journal of Yasar University, 2021, 16/64, 1836-1855

\title{
Does Relational Ethics in Family Influence the Relationship between Ethical Leadership \& Turnover Intention?
}

\section{Ailedeki İlişkisel Etik, Liderlik ve İşten Ayrılma Niyeti Arasındaki İlişsiyi Etkiler mi?}

\author{
Cigdem ASARKAYA, Istanbul Commerce University, Turkey, casarkaya @ ticaret.edu.tr \\ Orcid No: 0000-0002-5661-7996
}

Alev OZER TORGALOZ, İzmir Democracy University, Turkey, alevozertorgaloz@gmail.com

Orcid No: 0000-0002-0589-1231

\begin{abstract}
Öz: Son yıllarda, yeni nesillere mensup işgücünün sık sık iş değiştirdiklerine tanık olunmaktadır. Diğer bir deyişle, bu çalışanların düzenli olarak iş ve pozisyon değiştirmesi yeni normal haline gelmiştir. Öte yandan, literatürde (ör., Ongori, 2007), işgücü devrini en aza indirmenin, yetenek ve deneyim kaybetmenin potansiyel maliyetleri nedeniyle, kuruluşlar için kritik önem taşıdığına dair bir fikir birliği vardır. Bu çalışmada hedefimiz, etik liderliğin çalışanların işten ayrllma niyeti üzerindeki rolünü incelemek ve aile içindeki ilişkisel etiğin bu ilişkide düzenleyici bir etkiye sahip olup olmadı̆̆ını araştırmaktır. Bu çalışmanın bulguları, etik liderlik algılarının çalışanların işten ayrılma niyetleri üzerindeki negatif yönlü etkisini desteklemiştir. Bu bağlamda, bu çalışma işten ayrlma niyetine ilişkin anlayışımızı güçlendirmektedir. Öte yandan, aile içi ilişkisel etik değişkenine ilişkin olarak, hipotezlerimiz doğrultusunda beklediğimiz düzenleyici etki saptanmamıştır. Bulgularımız, etik liderliğin çalışanların kuruluşlarından ayrılma niyetlerini azaltıcı yöndeki rolünün altını çizmektedir.
\end{abstract}

\section{Anahtar Sözcükler: Etik Liderlik, İlişkisel Etik, İşten Ayrılma Niyeti, Kişi-Örgüt Uyumu Teorisi, Lider-Üye} Etkileșimi Teorisi

\section{JEL Siniflandirmasi: M10, M12, M19}

\begin{abstract}
Recent years have witnessed frequent job changes for the new generations. These changes have been coupled with a corresponding trend toward greater employment possibilities and availability of new positions. In this regard, it has become a new normal for employees to regularly change jobs and positions. On the other hand, there is an agreement within the literature (e.g., Ongori, 2007) that minimizing turnover of employees is critical for organizations due to the potential costs of losing talent and experience. In this research, our overreaching objective was to examine the role of ethical leadership over employees' intention to leave and to introduce relational ethics as a moderating factor on this relationship. The findings revealed the considerable impact of perceptions of ethical leadership on employees' intentions to leave. In other words, the results showed the explanatory effects of ethical leadership on employees' turnover intention. In this regard, this study enhances our understanding with regard to turnover intention. On the other hand, contrary to our expectations, no moderating effect with respect to relational ethics was observed. Our findings underline the critical role ethical leaders have on employees' intentions to leave their organizations.
\end{abstract}

Keywords: Ethical Leadership, Relational Ethics, Turnover Intention, Person-Organization Fit (P-O Fit) Theory, Leader-Member-Exchange (LMX) Theory

JEL Classification: M10, M12, M19

\section{Introduction}

Recent years have witnessed an increased turnover of employees and frequent job changes, especially for the new generations. These changes have been coupled with a corresponding trend toward greater employment possibilities and availability of new positions. In this regard, 
it has become a new normal for employees to regularly change jobs and positions. However, this has created a difficult problem for organizations with regard to sustaining employment, which can be considered as an important part of sustainable human resources management critical for organizational success (Ren \& Jackson, 2020). With increasing international competition, the importance of employing and retaining resources for competitiveness has increased (Li et al., 2017). In addition, retention has become one of the key priorities for human resources management policies of organizations due to the increasing mobility of employees. Specifically, retaining the talented employees is very critical for today's business world (Amankwaa \& AnkuTsede, 2015), as human capital is regarded as the most valuable resource (Ghaffari et al., 2021) Many efforts of talent management, in fact, can be considered as being directed towards making talents remain within the organization. Organizations are in need to detect the various reasons behind turnover intentions (TI). The importance of employee turnover for organizations has different dimensions. One of these dimensions is about the investments made in employees. According to Staw (1980), expenditures made on selection, recruitment, orientation and training of new employees are critical cost factors for organizations. Billions of dollars are spent per year for new employees to replace the leaving ones (Rosch, 2001). Therefore, losing experienced and trained employees causes significant problems, and it is necessary for organizations to develop ways to solve these problems.

While organizational factors play a critical role and there may be several other reasons why employees intend to leave their companies, we contend that the perception about leader's behavior has a considerable effect on these intentions. In this regard, this study aims to investigate how employees' ethical leadership (EL) perception contributes to a decrease in their turnover intention.

Several studies within the literature refer to the leader-member exchange (LMX) theory when explaining the effect of leaders on employee's turnover intention (e.g., Saeed et al., 2014; Jiang et al., 2019). In addition, there are studies on ethical leadership that use the framework of LMX (Mahsud et al., 2010; Walumbwa et al., 2011; Bhal \& Dadhich, 2011). Informed by the LMX theory, we contend that leaders have a critical role in employees' perception about their work and organizations.

On the other hand, individuals develop their ethical values based on different sources of experiences and influences. For most people, the strongest influence comes from their families. And people's perceptions about and attitudes towards others -including their supervisors- are also shaped by their own ethical values. Accordingly, we assume that together with the relational ethics derived from family-based ethical characteristics, ethical leadership has a vital 
effect on employees' decisions to leave the organization. This paper argues that if a person is raised in a family that -in general- practices principles of relational ethics (RE), then -when that person starts working- s/he will tend to have a higher expectation of ethical leadership at her/his workplace. Specifically, it is expected that, when they perceive unethical leadership especially, if practiced by their immediate supervisor- they will tend to have a higher turnover intention.

Having reviewed the related literature, we observe that relational ethics of employees and their ethical perceptions about their supervisors have not been studied together. There are studies considering relational ethics of leaders (e.g., Rhodes \& Badham, 2018; Crosweller \& Tschakert, 2020), however no association is investigated so far with regard to relational ethics in employees' family of origin. Sparked by this gap, we focus on the relational ethics on the side of employees, as we believe that employees' relational ethics assumptions accumulated in their private life so far would be critical for an association between their supervisors' ethics and their intention to leave the organization. We believe this can be due to a search of employees for convergence with their supervisors regarding ethical understandings. To explain this, we turn to both P-O fit and LMX theory, which claims that the relationship between an employee and his/her leader predicts individual or organizational outcomes (Gerstner \& Day, 1997).

We hope to make two key contributions to our audience and extant literature. Our first contribution relates to the context of our study. We collected data from industries in Turkey and in the aftermath of the outbreak of current Covid-19 pandemic. Given that most organizations shifted to remote working, the most connection of employees also shifted to their supervisors, rather than the organization as a whole. Therefore, we believe that findings of this study will provide implications for this context. Related to this contribution, we also hope to contribute to our knowledge in terms of the pivotal role leaders have on employee-related outcomes. We contend that supervisors have become important for employee decisions, for more than ever. Moreover, by linking relational ethics in employees' family of origin to the discussion of ethical leadership, and TI; we investigate the influence of a family of origin-related variable on workrelated outcomes.

The structure of the paper is as follows: In the first part of this paper, literature review on definitions of variables used in this study will be presented. Second part of the literature review will be devoted to theoretical background and hypothesis development. The study will continue with the methodology part, followed by the presentation of the analysis results. In the final part, discussion of the results, conclusions on implications of the study will be provided. 


\section{Literature Review}

Tett \& Meyer (1993) defined turnover intention as a deliberate willingness of an employee to leave the organization. In this study, we consider it as a tendency and decision to withdraw employment relations. Empirical research exploring the reasons of employee turnover within organizations stretches back to the early 70s (e.g., Hellriegel \& White, 1973; Porter \& Steers, 1973). It is a critical topic for organizations (Jang \& Kandampully, 2018) and commonly used as a proxy and predictor of actual turnover behavior within the related literature (e.g., Kim, 2005; Pitts et al., 2011; Cohen et al., 2016). This is relevant because it reflects employees' intentions about workplace behavior (Fishbein \& Ajzen 1971). In fact, various studies on employee turnover such as the study by Lambert et al. (2001) apply turnover intention as the dependent variable in their research models. In this current study, we also use intention to turnover as the indicator of turnover in general.

Not only cost factors, but also many other dimensions make turnover intention a critical issue for organizations. For example, it is negative for organizational effectiveness as it is likely that employees with unrealized turnover intentions turn to non-productive and/or withdrawal behavior (Chang et al., 2013). Human capital is a strategic value for organizations (Holtom et al., 2005) and it is argued that engagement and commitment of employees largely contribute to organizations' competitive advantage (Joo \& Park, 2010). Besides, performance of the remaining employees can be highly affected by the withdrawal of an employee (Yin-Fah et al., 2010). Decreasing employee morale and lower service quality perceived by customers (Gray et al., 2000) can be also added to the critical organizational results of high turnover, and this is why TI needs to be studied further.

The importance of studying the antecedents of turnover intention lies in identifying them and predicting TI timely so that measures can be taken to avoid turnover (Hwang \& Kuo, 2006). In line with prior research, we conceptualize turnover intention as the willingness by employees to leave their organization. There are, in fact, many antecedents suggested within the literature. According to Chang et al. (2013) job satisfaction, rewarding system, social support, employee commitment and several demographic characteristics are among the mostly analyzed antecedents of turnover intention. In the rest of the paper, we attempt to investigate how TI of employees may be revealed by considering some ethics-related variables.

Ethical Leadership (EL) stands at the core of being a good leader. This situation is reflected in different ways within the leadership literature. For instance, one of the dimensions of transformational leadership is 'idealized influence', which is explained as usually having "very 
high standards of moral and ethical conduct"; and such leaders are described as people who can be trusted to do the right thing (Northouse, 2016, p. 167).

Northouse (2016) states the principles of ethical leadership as follows: respecting others, serving others, showing justice, manifesting honesty, and building community (p. 341). The first four do not require much explanation. On the other hand, while 'building community', an ethical leader considers purposes of the members of the group and takes into account "the interests of the community", rather than imposing her/ his will on others (p. 347).

Yukl et al. (2013), who have proposed a measure of EL, mentioned different descriptions of EL, two of which are as follows:

- Ethical leaders engage in acts and behaviors that benefit others, and at the same time, they refrain from behaviors that can cause any harm to others (Kanungo, 2001).

- The combination of integrity, ethical standards, and fair treatment of employees are the cornerstones of ethical leadership (Brown, Trevino, and Harrison; 2005). (in Yukl et al., 2013, p. 38)

After reviewing research on previous measures of EL, Yukl et al. (2013) regard the following characteristics as most relevant for EL: "honesty and integrity, behavior intended to communicate or enforce ethical standards, fairness in decisions and the distribution of rewards, and behavior that shows kindness, compassion, and concern for the needs and feelings of others" (p. 40-1).

Moreover, Brown et al. (2005), who refer to some more comprehensive formulations of EL; define ethical leadership "as the demonstration of normatively appropriate conduct through personal actions and interpersonal relationships, and the promotion of such conduct to followers through two-way communication, reinforcement, and decision-making" (p.120).

Relatedly, Heres and Lasthuizen (2010) mention three components of EL: the moral person, the moral manager, and a high-quality leader-follower relationship (p. 2). The moral person is related with integrity of the leader, and the moral manager concerns the degree to which s/he is "able to cultivate integrity among his or her followers ... (Treviño, Hartman, \& Brown 2000)" (in Heres \& Lasthuizen, 2010, p. 2). The third component, quality of leader-follower relationship, connects the other two.

Relational Ethics (RE) is about "the subjective balance of trustworthiness, justice, loyalty, merit and entitlement between members of a relationship" (Hargrave et al., 1991, p.146). It mentions the responsibility of the members to balance what they give and take with respect to these qualities. When this balance is reached, the "innate sense of fairness is satisfied (Boszormenyi-Nagy \& Krasner, 1980)" (in Hargrave et al., 1991, p.146). Analysis of the 
authors indicated that trust and justice constructs in their RE measure were strong in differentiating between "dysfunctional and well-adjusted groups" (p.157). In the current study, RE refers only to RE in one's family of origin.

Boszormenyi-Nagy (1986) states that RE “emphasizes responsibility for consequences for others", and that both positive and negative consequences have an influence on a child's "capacity for trust" (p.197). For instance, if there is a trustworthy family environment, children of that family will tend to expect to meet with trustworthy people in other social environments (vice versa). Hargrave et al. (1991) also mention that individuals who experience fair family exchanges in giving and taking, "will carry a balanced ethic into other relationships ... (Boszormenyi-Nagy \& Spark, 1984)" (in Hargrave et al., 1991, p.147). This emphasis of 'carrying' overlaps with the expectation of the model investigated in the current study, which proposes that relational ethics in one's family of origin may influence her/ his perceptions about supervisors, and consequent attitudes at work. Specifically, we expect to find a stronger relationship between EL perceptions and TI of employees who experienced higher RE in their families. In other words, if people are used to being treated fairly in their families, they will expect such treatment in their workplaces. Consequently, if they don't perceive such treatment, they will have a higher intention to turnover.

Finally, Ochs and Kremer- Sadlik (2007) point to the important influence of families on their children's morality, such that children learn how to treat others, and build social relationships from their family members. The authors also emphasize that "morality is embedded in and is an outcome of everyday family practices", as these practices include "messages about right and wrong, better and worse, rules, norms, obligations, duties, etiquette, moral reasoning, virtue, character" (p. 5). This interpretation indirectly supports the potential interaction between perceptions of EL and RE in the current research.

\section{Theoretical Background and Hypotheses Development}

Kristof (1996), who provided an integrative review of P-O fit conceptualizations, utilized the following definition of P-O fit: "the compatibility between people and organizations that occurs when: (a) at least one entity provides what the other needs, or (b) they share similar fundamental characteristics, or (c) both" (p. 4-5). The author also emphasizes the influence of self-awareness such that those who are more aware of their values, goals, and personality may tend to be more attentive to those properties in organizations.

Chatman (1989) defines P-O fit as "the congruence between the norms and values of organizations and the values of persons" (p. 339). She presented a model of person-organization 
fit, in which there is also an emphasis on the influence of individual values on P-O fit. Our model has an assumption of individual values behind its utilization of RE. In other words, we hypothesize that individuals' expectations from their supervisors would also be influenced by the climates and routines in their family of origin.

Edwards (2008) mention that if person- environment fit is based on a "subjective judgment of the match between the person and environment (Locke, 1969, 1976; Wanous, 1980; Schneider, 1983)", it can be regarded as a "distinct construct" (p. 220). There is such an assumption of subjective reasoning behind our hypothesis related with EL and TI; and that reasoning is expected to be influenced by RE. Andrews et al. (2011) rightfully point to the growth of unethical cases in organizations and highlight the importance of understanding influencers around the concept of P-O fit better. The authors mention the following definition of P-O fit: "the level of compatibility in terms of values, beliefs (Netemeyer et al., 1997), personality (Christiansen et al., 1997) and/or goals (Kristof, 1996) between individuals and the organization" (in Andrews et al., 2011, p.6). They also state that, "most empirical research has focused on the values component of P-O fit (Hoffman \& Woehr, 2006)" (in Andrews et al., 2011, p.8). Finally, they point to the consistent empirical findings that present positive outcomes, such as reduced turnover (Hoffman \& Woehr, 2006), as related with strong P-O fit (in Andrews et al., 2011, p.8). Parallel to this, DeGeorge (1990) argues that employees who believe that they do not fit in the organization usually do not continue to work there.

Ambrose et al. (2007) found that the fit between personal and organizational ethics decreases turnover intention of the employee. The authors state that there are two approaches that investigate individuals' ethics in workplaces. One of them focuses on individuals' ethical orientations, which is also the case in our research. Such studies concentrate on issues like “cognitive moral development (Kohlberg, 1981, 1984)" and "individual ethical frameworks (Jubb, 1999; Judge \& Martocchio, 1996)" of the individual, and their influence on individuals' attitudes and behaviors (in Ambrose et al., 2007, p. 323). The second approach is interested in organizational characteristics that may have an influence on moral attitudes and behavior of individuals at work. Moreover, Ambrose et al. (2007) mention that "the congruence between individual and organizational values (Chatman, 1989; Judge and Bretz, 1992)" stands at the core of person-organization (P-O) fit, and it was found to be affecting employee attitudes and behaviors, such as "commitment, satisfaction, and turnover intentions (O'Reilly et al., 1991)" (in Ambrose et al., 2007, p.324). This argument of Ambrose et al. (2007) is a different formulation of our hypotheses. We argue that the level of relational ethics in an individual's family may have reflections on the influence of that individual's perceptions of EL on her/ his 
turnover intention. Specifically, coming from a family with high RE, a person is hypothesized to have a stronger connection between her/his perceptions of EL and turnover intention.

Moreover, Schminke et al. (2005) mentions that some studies about value congruence in organizations concentrate on "congruence between the values of different individuals (e.g., employees and supervisors, coworkers)" (p.139). The authors found that the congruence between the highest-ranking leader's moral development and the employee's moral development was negatively related with turnover intentions. In other words, conditions of congruence were associated with the lowest turnover intentions. Lastly, Schminke et al. (2005) reported that "attitudes deteriorate more rapidly when the employee's moral development exceeds that of the leader" (p.148). Again, our hypotheses may be regarded as an indirect way of representing employee's need for such a congruence. Furthermore, we expect that there would be even a stronger relationship between value congruence with immediate supervisor and employee attitudes.

Many contextual and personal factors affect the intention to leave (Bothma \& Roodt, 2013). Employees want to fit into their work environments and once they do not fit, they tend to leave the organizations (Chen et al., 2016). Although HR departments today are increasingly trying to calculate the possibilities of turnovers in advance, some dimensions are not likely to be observed at all, and perception about leader's behavior is one of them. Studies on turnover intention and LMX have pointed out, that interactions between employees and their immediate supervisors affect employees' turnover intention (Kim et al., 2017). In fact, Harris et al. (2009) empirically reveal the negative relationship between LMX and turnover intention. Employees increasingly recognize the value of their supervisors' constructive behavior. Leaders are usually perceived as idols for employees (Morris, Brotheridge, \& Urhanski, 2005). High turnovers may also be related with poor supervisory practices (O'Connell \& Kung, 2007; Ongori, 2007). At this point, specifically supervisory justice also reflects employees' perception about organizational justice (Kim et al., 2017). When employees feel their emotional resources to be threatened due to several workplace problems, they tend to feel isolated and a lower level of belonging leads to the intention to leave (Rappaport, 1981). Furthermore, research by Zhang et al. (2012) reveals that congruence between employees and their leaders with regard to psychological characteristics can affect employees' work-related outcomes, and this is explained via LMX.

Mossholder et al. (2005) link turnover to ineffective leadership. When considering good leadership practices, ethical behavior mostly come first and therefore, ethical leadership is chosen in this study as the initial point of the research model. Ethical leadership has attracted 
extensive attention among scholars on management. Prior research on the implications of ethical leadership has predominantly focused on the employee-related outcomes (e.g., Avey et al., 2011; Mayer et al., 2012; Lu \& Lin, 2014). Several studies (e.g., Suifan et al., 2020; Nejati et al., 2020; Shareef \& Atan, 2019; Shafique et al., 2018; Lin \& Liu, 2017; Demirtas \& Akdogan, 2015; Tang et al., 2015; Elci et al., 2012) have in fact investigated the effects of ethical leadership on turnover intention. Further, Trevino et al. (1998) interpret the findings of their research as an indication of the relationship between an ethical work context and employees' organizational commitment. This may be considered as an indirect support for our hypothesis between EL and TI, as higher commitment may be regarded as a reflection of lower intention to leave. The current study is an attempt to provide empirical support for the effect of leadership, and specifically ethical leadership, as an antecedent of turnover intention.

We suggest the first hypothesis as:

H1: There is a significant and negative relationship between ethical leadership and turnover intention.

An interesting research by Liao et al. (2008) present the positive influence of perceived deep-level dissimilarity on employee's behaviors of work withdrawal and voluntary turnover. They explain the concept of deep-level characteristics that cannot be directly observed, by providing examples like personality and personal values. The authors tie the explanation of this finding to:

the similarity-attraction paradigm (Byrne, 1971) and the social identity perspective (Tajfel \& Turner, 1986; Turner, 1987), which ... suggest that similarities or differences between group members would form the basis for interpersonal attraction and categorization of group members into in-groups and out-groups. (Liao et al., 2008, p.107).

Finally, they emphasize that turnover can be reduced by increasing the "fit between jobs and other aspects of life" (p.121). This research can be regarded as providing indirect support for our hypotheses, as relational ethics may also be considered as related with personality and values.

In addition, Loughlin and Barling (2001) explored the influence of family work experiences on young workers' work values, attitudes and behaviors. The authors state that there is "strong evidence that children's perceptions of parental work attitudes and experiences shape the development of their own work beliefs and attitudes (Barling, Dupre, \& Hepburn, 1998)" (Loughlin and Barling, 2001, p. 545). Although they consider specifically the work-related 
experiences of parents, their approach reflects the potential influence of parents' attitudes on their children's attitudes.

Coldwell et al. (2008) presented a finding from "National Business Ethics Survey conducted in America (National Business Ethics Survey, 2003)": 97\% of employees who thought that their supervisors demonstrated ethical actions of "talking about ethics at work, keeping promises and commitments, supporting employees who follow ethical standards and modelling ethical behavior", were satisfied with their organizations (p. 617). The authors also made some future research suggestions, one of which is the empirical analysis of the influence of levels of moral development of employees on their perceptions of "organizational ethical climates and their concomitant turnover" (p. 620). This suggestion has considerable conceptual overlap with our investigation. In addition, the authors state that employees base their perceptions about their organizations on their personal ethical expectations, which provides indirect support for our hypothesis about RE.

O'Reilly et al. (1991) found a correlation of $r=-.37(p<.01)$ between person-organization fit at the time of entrance to the firm, and intent to leave one year later (p. 504). The authors regard their findings as a reflection of the importance of organizational culture on employeerelated outcomes. Likewise, Sims and Kroeck (1994) found partial support for their hypothesis expecting a lower intention to turnover for employees who achieve a match between their current ethical work climate and their preferences.

Thus, we suggest the second hypothesis as:

$\mathrm{H}$ 2: RE moderates the relationship between EL and TI such that the relationship will be stronger when RE is higher.

The research model is presented in Figure 1.

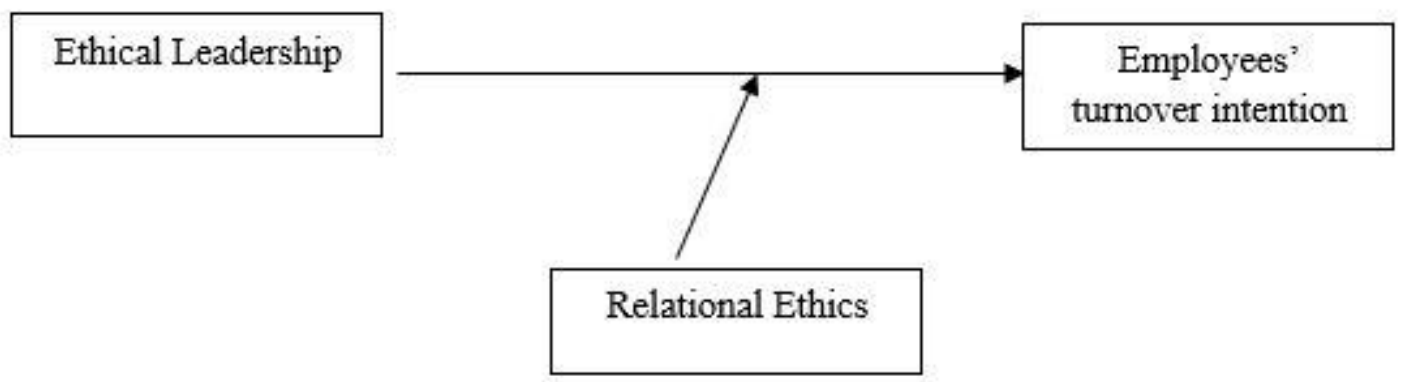

Figure 1. Research model 


\section{Methodology}

The sample of this study were professionals from education (36\%), production (18\%), services (16\%) and others including health sector $(28 \%)$ in Turkey. With regard to the respondents, convenience sampling method was applied. To collect data, an online questionnaire was prepared and sent to the respondents via e-mail by asking their consent and explaining the objective of the research. Participants were informed that participation was anonymous and voluntary. We collected 171 surveys in order to test our hypotheses. To provide a better insight with regard to the sample, demographic information, including gender, age, marital status, education and etc. were asked in the questionnaires. Table I provides the demographic characteristics of the respondents.

Table 1. Demographics of respondents

\begin{tabular}{|c|c|c|}
\hline Demographics & Items & Percent $(\%)$ \\
\hline \multirow[t]{2}{*}{ Gender } & Male & $47 \%$ \\
\hline & Female & $53 \%$ \\
\hline Age & Average & 39.4 \\
\hline \multirow{3}{*}{ Education } & Bachelor's degree & $33 \%$ \\
\hline & Master's degree & $26 \%$ \\
\hline & PhD degree & $40 \%$ \\
\hline \multirow[t]{2}{*}{ Marital Status } & Single & $34 \%$ \\
\hline & Married & $66 \%$ \\
\hline \multirow[b]{2}{*}{ Having children } & Yes & $53 \%$ \\
\hline & No & $47 \%$ \\
\hline \multirow[t]{2}{*}{ Public / private sector information } & Public & $39 \%$ \\
\hline & Private & $61 \%$ \\
\hline \multirow{5}{*}{ Industry Information } & Education & $36 \%$ \\
\hline & Production & $18 \%$ \\
\hline & Service & $16 \%$ \\
\hline & Health & $3 \%$ \\
\hline & Other & $27 \%$ \\
\hline Total work experience & Average & 15.7 years \\
\hline Experience in current organization & Average & 7.6 \\
\hline Experience with current supervisor & Average & 3.7 \\
\hline Father alive & Average & $75 \%$ \\
\hline Mother alive & Average & $92 \%$ \\
\hline
\end{tabular}




\section{Findings}

Our research model includes three constructs, and thus the questionnaire contained three scales: ethical leadership, relational ethics, and turnover intention. All scales used were originally in English, thus they were first translated to Turkish and then back translated to English, as suggested by Brislin (1980). The translations were checked by the two authors.

Ethical leadership scale was derived from Brown, Trevino and Harrison (2005)'s measure. Respondents were asked to choose, on a 5-point Likert scale, their degree of agreement or disagreement with the items ( $1=$ highly unlikely, $5=$ highly likely). The original scale contains 10 survey items however three items were purified and left out as a result of the factor analysis. Our final scale contains 7 items (Cronbach's $\alpha=0.937)$ and it has a mean of $3.41(\mathrm{SD}=1.13)$. Sample items include "My supervisor can be trusted" and "My supervisor disciplines employees who violate ethical standards".

First, exploratory factor analysis (EFA) was conducted to test the variables and to define them with regard to their underlying factors (Hair et al., 2006). Accordingly, for ethical leadership, EFA explained $68.7 \%$ of the variance and KMO measure showed adequate sampling adequacy $(\mathrm{KMO}=0.918)$, meaning that the data were suitable for factor analysis. All item loadings on the theorized construct were significant at the $\mathrm{p}<0.001$ level and no modifications were conducted. Next, confirmatory factor analysis (CFA) was conducted to test the construct validity and to evaluate how well the data fits the measurement model. CFA revealed that the model showed good and acceptable fit indices $(\mathrm{cmin} / \mathrm{df}=3,021, \mathrm{CFI}=0.971, \mathrm{GFI}=0.935$, RMSEA=0.109).

In this research the RE measure developed by Hargrave et al. (1991) is utilized. It is worth noting that the vertical subscales are related with the asymmetrical relationships, related with one's parents for instance; and the horizontal subscales are related with relationships between partners of equal positions. Thus, horizontal subscales were left out, as this study focuses on the interaction between family- and supervisor-related constructs. In addition, the vertical loyalty subscale of the RE scale was not utilized, as the loyalty-related items were not considered to be relevant for our model. Therefore, the subscales of "vertical trust and justice" and "vertical entitlement" were utilized. Respondents were asked to choose, on a 5-point Likert scale, their degree of agreement or disagreement with the items $(1=$ strongly disagree, $5=$ strongly agree). The original scale has 9 items, however two items were purified and left out as a result of the factor analysis, and the resulting scale contains 7 items (Cronbach's $\alpha=0.812$ ) and it has a mean of $4.12(\mathrm{SD}=0.672)$. Sample items include "I often felt deserted by my 
family" (vertical trust and justice) and I felt my life was dominated by my parents' desires (vertical entitlement).

First, exploratory factor analysis (EFA) was conducted to test the variables and to define them with regard to their underlying factors (Hair et al., 2006). Accordingly, for relational ethics, EFA explained 49,6\% of the variance and KMO measure showed adequate sampling adequacy $(\mathrm{KMO}=0.841)$. As a result of the confirmatory factor analysis, two more items were purified. (Cronbach's $\alpha=0.86$, mean $=4.44, \mathrm{SD}=0.7$ ). All five item loadings on the theorized construct were significant at the $\mathrm{p}<0.001$ level.

Next, confirmatory factor analysis (CFA) was conducted to test the construct validity and to evaluate how well the data fits the measurement model. Final CFA revealed that the scale showed good and acceptable fit indices $(\mathrm{cmin} / \mathrm{df}=1.879, \mathrm{CFI}=0.988, \mathrm{GFI}=0.978, \mathrm{RMSEA}=$ 0.072).

Turnover intention scale was derived from Mobley, Horner and Hollingsworth (1978)'s measure. Respondents were asked to choose, on a 5-point Likert scale, their degree of agreement or disagreement with the items ( $1=$ strongly disagree, $5=$ strongly agree). The scale contains 3 items (Cronbach's $\alpha=0.933)$ and it has a mean of $2.76(\mathrm{SD}=1.37)$. Sample items include "I think a lot about leaving the organization" and "I am actively searching for an alternative to the organization".

First, exploratory factor analysis (EFA) was conducted to test the variables and to define them with regard to their underlying factors (Hair et al., 2006). Accordingly, for turnover intention, EFA explained $88.38 \%$ of the variance and KMO measure showed a moderate sampling adequacy $(\mathrm{KMO}=0.768)$, meaning that the data were suitable for factor analysis. All item loadings on the theorized construct were significant at the $\mathrm{p}<0.001$ level and no modifications were conducted.

Next, confirmatory factor analysis (CFA) was conducted to test the construct validity and to evaluate how well the data fits the measurement model. Final CFA revealed that the turnover intention scale -due to a small number of items- resulted in a lack of degrees of freedom and consequently in the following fit indices $(\mathrm{Cmin} / \mathrm{df}=$ none, $\mathrm{CFI}=1.000$, $\mathrm{GFI}=1.000, \mathrm{RMSEA}=0.914)$.

Means, standard deviations and correlation numbers in relation to each variable is provided in Table 2 and Table 3 below. 
Table 2. Means, standard deviations and reliabilities of variables

\begin{tabular}{|c|c|c|c|}
\hline Construct & Mean & Std. Dev. & Cronbach's Alpha \\
\hline Ethical Leadership & 3.41 & 1.13 & 0.94 \\
\hline Relational Ethics & 4.44 & 0.70 & 0.86 \\
\hline Turnover Intention & 2.76 & 1.37 & 0.93 \\
\hline
\end{tabular}

Table 3. Correlations

\begin{tabular}{|l|c|c|c|}
\hline \multirow{2}{*}{ Constructs } & \multicolumn{3}{|c|}{ Correlations (Spearman) } \\
\cline { 2 - 4 } & Ethical Leadership & Turnover Intention & Relational Ethics \\
\hline Ethical Leadership & & $-0,593(\mathrm{p}<0.000)$ & $0,013(\mathrm{p}=0.87)$ \\
\hline Turnover Intention & & & $0,000(\mathrm{p}=0.997)$ \\
\hline & & & \\
\hline
\end{tabular}

a) H1: Ethical leadership negatively affects turnover intention of employees.

Before testing the direct effects among the variables, correlation tests were conducted. Even though we calculated cube of EL, to normalize this variable, we could not attain normality. This is why we made use of Spearman's rho correlation. The results showed that ethical leadership was negatively correlated with turnover intention ( $\mathrm{r}:-0.609, \mathrm{p}<0.000)$, as it was expected. The result is as follows (see Table 4):

Table 4. Correlations

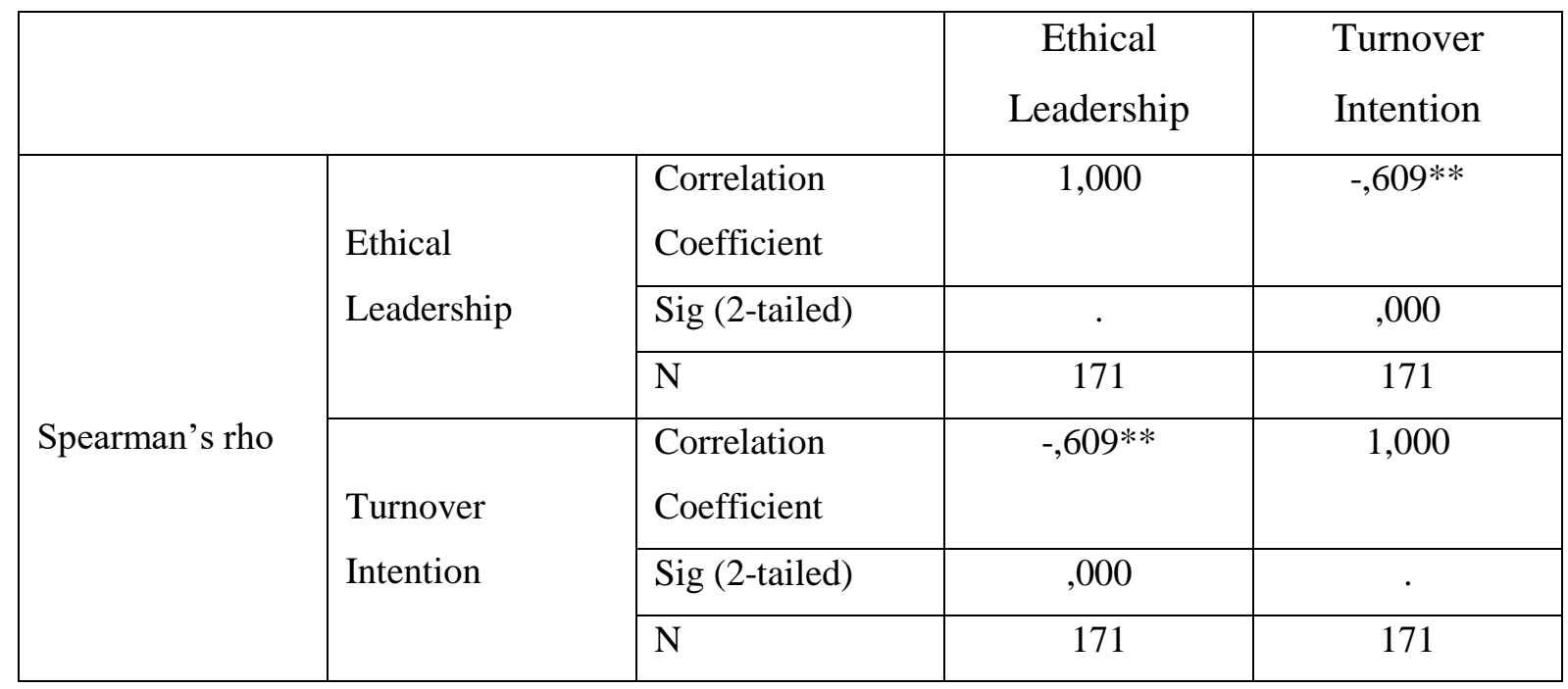

** Correlation is significant at the 0.01 level (2-tailed) 
Next, we investigated the regression between EL and TI and found a significant and negative relation between them. The first hypothesis predicted that ethical leadership was negatively associated with turnover intention. The results showed that those who had ethical leaders as supervisors were less likely to develop turnover intention $(b=-.532, p=0.000)$. The strength of this relationship shows a moderate level of statistical relation. Thus, Hypothesis 1 was supported. The relevant SPSS result is available below (see Table 5):

Table 5. Coefficients

\begin{tabular}{|l|c|c|c|c|c|}
\hline \multirow{2}{*}{ Model } & \multicolumn{2}{|l|}{} & \multirow{2}{*}{$\mathrm{t}$} & \multirow{2}{*}{ Sig. } \\
\cline { 2 - 4 } & $\mathrm{B}$ B & Std. Error & Beta & & \\
\hline 1 (constant) &,- 089 &, 066 & & $-1,350$ &, 179 \\
\hline $\begin{array}{l}\text { Ethical } \\
\text { Leadership }\end{array}$ &,- 209 &, 026 &,- 532 & $-8,178$ &, 000 \\
\hline
\end{tabular}

Dependent Variable: Turnover intention

We also cross-checked this SPSS regression result with that in Amos. The results are perfectly parallel, as displayed in the table below (Table 6).

b) H2: Relational ethics moderates the relationship between ethical leadership and turnover intention.

Hypothesis 2 was not supported. The moderation effect was insignificant (Sig: .234; Estimate: .008). The relevant result is presented in the table below (Table 6).

Table 6. Regression Weights

\begin{tabular}{|l|l|l|l|l|}
\hline & Estimate & S.E. & C.R. & P \\
\hline Turnover int < --- Ethical Leadership &,- 205 &, 025 & $-8,065$ & $* * *$ \\
\hline Turnover int < --- Relational Ethics &, 006 &, 013 &, 492 &, 623 \\
\hline Turnover int < --- Ethical lead x relational eth. &, 008 &, 007 & 1,191 &, 234 \\
\hline
\end{tabular}

\section{Discussion and Conclusion}

Turnover remains as a critical problem for organizations (O'Connell \& Kung, 2007; Bachri \& Solekah, 2021). Prediction of turnover intentions may continue to constitute an issue for organizations in the future. Though HR professionals will use several tools for such a prediction, employees' perceptions such as ethical behavior at workplace may also play an 
important role. Efforts that focus on the antecedents of turnover intention should be multidimensional.

Lambert et al. (2001) state that turnover intention is a critical factor for organizations also with regard to financial results. Schwepker Jr. (2001) claims that employees desiring an ethical climate are less likely to leave their work when they perceive such a climate. The relevance of a discussion of ethical leadership is derived from here. Supervisors establish a significant part of employees' perception about the organization due to their direct interaction with their subordinates. Study by Kim et al. (2017) reveals the role of supervisors in affecting organization-employee relationship quality and its outcomes. In this study, it is well documented that supervisors' ethical behavior is essential for employees' perception of the work environment and that they are considerably influential in generating employees' intention to stay or not. Drawing from the conversation on P-O fit and LMX theories, the current study investigates how ethical leadership is associated with TI of the employee and the potential moderating influence of RE on this relationship.

We collected 171 surveys in order to explore our hypotheses. The results showed that the employees who had more ethical supervisors, were less likely to have turnover intention $(b=-$ $.532, \mathrm{p}=0.000$ ). Thus, Hypothesis 1 was supported. On the other hand, Hypothesis 2 was not supported. The moderation effect of RE was insignificant (Sig: .234; Estimate: .008).

RE scores of the current sample were not normally distributed. Our sample was a highly educated group, $40 \%$ of which had a $\mathrm{PhD}$ degree. This may have led to a bias, compared to the average of Turkish society, in terms of higher RE scores. Further, it may also be interpreted such that our sample does not support this moderating influence hypothesized in H2. Further exploration with different samples may prove useful.

In general, investigations about work and personal life relationships are based on employees' current families. This study has a different perspective of questioning the influence of family of origin on one's work-related attitudes. This perspective may well be regarded as a conceptual contribution. In the review of literature, no research about the influence of RE in family on children's work-related attitudes, and interaction effect of RE with children's EL perceptions could be found.

Our research model was a first attempt within the literature to integrate the concept of relational ethics within the discussion on the relationship between ethical leadership and employee turnover. In addition, our findings provide several implications for organizational practice on understanding the factors leading to intention to leave. Practically, the implementation of ethical leadership by supervisors will serve to decrease the loss of 
experienced and talented human resource. Therefore, it can be argued that ethical quality of supervisors should be a priority for organizations.

As with all studies, this study has some limitations that may inform future research. The lack of support for $\mathrm{H} 2$ can be explained with some of the characteristics of this study such as the highly educated participants and the limited sample size. Different results could be obtained when the sample included a wider variety of people reflecting cultural, educational and ethical diversity. Secondly, responses to the questionnaire were collected from companies only in Turkey. Future studies can further extend this research by making cross-cultural comparisons with data from different countries. Thirdly, this study included only one construct to test for moderation. It would be advisable to conduct this research by including several other variables as moderator.

There is an agreement within the literature (e.g., Ongori, 2007) that minimizing turnover of employees is critical for organizations due to the potential costs of losing talent and experience. In this research, our overreaching objective was to examine the role of ethical leadership over employees' intention to leave and to introduce relational ethics as a moderating factor on this relationship. The findings revealed the considerable impact of perceptions of ethical leadership on employees' intentions to leave. In other words, the results showed the explanatory effects of ethical leadership on employees' turnover intention. In this regard, this study enhances our understanding with regard to turnover intention. On the other hand, contrary to our expectations, no moderating effect with respect to relational ethics was observed. Our findings underline the critical role ethical leaders have on employees' intentions to leave their organizations. Therefore, organizations need to focus also on the ethical quality of supervisors when working on retention problems.

Our first contribution is related with the context of the study. We collected data from industries in Turkey and during the Covid-19 pandemic. As mentioned before, the most connection of employees also shifted to their supervisors. We also contribute to our knowledge in terms of the essential role leaders have on employee-related outcomes. Specifically, our study would be providing further support for the critical role of ethical leadership, on the turnover intentions of employees. Finally, by linking ethical perceptions of employees related with their families of origin to the discussion of ethical leadership, and turnover intention; we investigate the influence of a family-related variable on work-related outcomes. 


\section{REFERENCES}

Amankwaa, A., and Anku-Tsede, O. "Linking Transformational Leadership to Employee Turnover: The Moderating Role of Alternative Job Opportunity." International Journal of Business Administration 6, no .4 (2015): 19-29.

Ambrose, M. L., Arnaud, A. and Schminke, M. "Individual Moral Development and Ethical Climate: The Influence of Person-Organization Fit on Job Attitudes.” Journal of Business Ethics 77 (2008): 323-333.

Andrews, Martha C., Thomas Baker, and Tammy G. Hunt. "Values and person-organization fit: Does moral intensity strengthen outcomes?" Leadership \& Organization Development Journal 32, no. 1 (2011): 5 19.

Avey, J. B., Palanski, M. E., and Walumbwa, F. O. "When Leadership Goes Unnoticed: The Moderating Role of Follower Self-Esteem on the Relationship Between Ethical Leadership and Follower Behavior." Journal of Business Ethics 98, no.4 (2011): 573-582.

Bachri, F., and Solekah, N. A. "Organizational Commitment as Mediating Variable of Employee Job Satisfaction Toward Turnover Intentions.” INOBIS: Jurnal Inovasi Bisnis dan Manajemen Indonesia 4, no.2 (2021): 151-162.

Bhal, K. T. and Dadhich, A. "Impact of Ethical Leadership and Leader-Member Exchange on Whistle Blowing: The Moderating Impact of the Moral Intensity of the Issue.” Journal of Business Ethics 103, no. 3 (2011): 485-496.

Boszormenyi-Nagy, I. "Transgenerational Solidarity: The Expanding Context of Therapy and Prevention." The American Journal of Family Therapy 14, no. 3 (1986):195-212

Bothma, C. F. C. and Roodt, G. "The Validation of The Turnover Intention Scale." Journal of Human Resource Management 11, no. 1 (2013).

Brislin, R. W. "Translation and content analysis of oral and written material”, in Triandis, H.C. \& Berry, J. W. (Eds.), Handbook of Cross-Cultural Psychology (pp. 389-444) (Allyn and Bacon, 1980).

Brown, M. E., Treviño, L. K. and Harrison, D. A. "Ethical Leadership: A Social Learning Perspective for Construct Development and Testing." Organizational Behavior and Human Decision Processes 97, no.2 (2005): 117-134.

Chang, W. J. A., Wang, Y. S., and Huang, T. C. "Work Design-Related Antecedents of Turnover Intention: A Multilevel Approach.” Human Resource Management 52, no.1 (2013): 1-26.

Chatman, J. "Improving Interactional Organizational Research: A Model of Person-Organization Fit." Academy of Management Review 14 (1989): 333-349.

Chen, Y., Wen, Z., Peng, J., and Liu, X. "Leader-Follower Congruence in Loneliness, LMX And Turnover Intention.” Journal of Managerial Psychology 31, no. 4 (2016): 864-879.

Cohen, G., Blake, R. S. and Goodman, D. "Does Turnover Intention Matter? Evaluating the Usefulness of Turnover Intention Rate as A Predictor of Actual Turnover Rate." Review of Public Personnel Administration 36, no.3 (2016): 240-263.

Coldwell, D. A., Billsberry, J., van Meurs, N. and Marsh, P. J. G. "The Effects of Person-Organization Ethical Fit on Employee Attraction and Retention: Towards a Testable Explanatory Model. " Journal of Business Ethics 78, (2008): 611-622.

Crosweller, M. and Tschakert, P. "Climate Change and Disasters: The Ethics of Leadership." Wiley Interdisciplinary Reviews: Climate Change 11, no.2 (2020): 624.

DeGeorge, R. T. Business Ethics (3rd ed.). (New York: Macmillan, 1990).

Demirtas, O. and Akdogan, A. A. "The Effect of Ethical Leadership Behavior on Ethical Climate, Turnover Intention, And Affective Commitment." Journal of Business Ethics 130, no.1 (2015): 59-67.

Edwards, J. R. "Person-Environment Fit in Organizations: An Assessment of Theoretical Progress." Academy of Management Annals 2, (2008): 167-230

Elçi, M., Şener, İ., Aksoy, S., and Alpkan, L. "The Impact of Ethical Leadership and Leadership Effectiveness on Employees' Turnover Intention: The Mediating Role of Work-Related Stress.” Procedia-Social and Behavioral Sciences 58, (2012): 289-297.

Fishbein, M. F. and Ajzen, O. R. "Turnover Intention and Transfer Rate as Indicators of Employees' Dissatisfaction." Journal of Industrial Labour Relation 21, no.4 (1971): 15-17.

Gerstner, C. R. and Day, D. V. "Meta-Analytic Review of Leader-Member Exchange Theory: Correlates and Construct Issues.” Journal of Applied Psychology 82, no.6 (1997): 827.

Ghaffari, M., Aghadavood, S. R., and Dalvi, M. R. "The Impact Study of the Role of Job Rotation System Effectiveness on Work Enthusiasm." Nexo Revista Cientifica 34, no. 2 (2021): 790-806.

Gray, R. A., Niehoff, B. P. and Miller, J. L. "The Effect of Job Characteristics on Student Employee Job Satisfaction and Intent to Turnover in College and University Foodservice." Journal of the National Association of College \& University Foodservices 21, (2000): 14-29.

Hair, J. F., Black, W. C., Babin, B. J., Anderson, R. E., and Tatham, R. L. Multivariate data analysis (6th edition). (New Jersey: Pearson Education, 2006). 
Hargrave, T. D., Jennings, G., and Anderson, W. "The Development of a Relational Ethics Scale.” Journal of Marital and Family Therapy 17, (1991): 145-158

Harris, K. J., Harris, R. B. and Brouer, R. L. "LMX and Subordinate Political Skill: Direct and Interactive Effects on Turnover Intentions and Job Satisfaction.” Journal of Applied Social Psychology 39, no.10 (2009): 2373-2395.

Hellriegel, D. and White, G. E. "Turnover of Professionals in Public Accounting: A Comparative Analysis." Personnel Psychology 26, (1973): 239-249.

Heres, L. and Lasthuizen, K. "Ethical Leadership: A Variform Universal Phenomenon." in Annual Conference of the European Group for Organizational Studies, (2010, August): 1-3.

Holtom, B. C., Mitchell, T. R., Lee, T. W., and Inderrieden, E. J. "Shocks as Causes of Turnover: What They Are and How Organizations Can Manage Them.” Human Resource Management 44, (2005): 337-352.

Hwang, I. and Kuo, J. "Effects of Job Satisfaction and Perceived Alternative Employment Opportunities on Turnover Intention: An Examination of Public Sector Organizations.” The Journal of American Academy of Business 8, (2006): 254-259.

Jang, J. and Kandampully, J. "Reducing Employee Turnover Intention Through Servant Leadership in The Restaurant Context: A Mediation Study of Affective Organizational Commitment." International Journal of Hospitality \& Tourism Administration 19, no.2 (2018): 125-141

Jiang, W., Wang, L., Chu, Z., and Zheng, C. "Does Leader Turnover Intention Hinder Team Innovation Performance? The Roles of Leader Self-Sacrificial Behavior and Empathic Concern.” Journal of Business Research 104, (2019): 261-270.

Joo, B. B. and Park, S. "Career Satisfaction, Organizational Commitment, and Turnover Intention: The Effects of Goal Orientation, Organizational Learning Culture and Developmental Feedback." Leadership \& Organization Development Journal 31, no.6 (2010): 482-500.

Kim, S., Tam, L., Kim, J.-N. and Rhee, Y. "Determinants of Employee Turnover Intention: Understanding the Roles of Organizational Justice, Supervisory Justice, Authoritarian Organizational Culture and Organization-Employee Relationship Quality." Corporate Communications: An International Journal 22, no.3 (2017): 308-328.

Kim, S. "Factors Affecting State Government Information Technology Employee Turnover Intentions." The American Review of Public Administration 35, (2005): 137-156.

Kristof, A. L. "Person-Organization Fit: An Integrative Review of Its Conceptualizations, Measurement, and Implications." Personnel Psychology 49, no.1 (1996): 1-49.

Lambert, E. G., Lynne Hogan, N. and Barton, S. M. "The Impact of Job Satisfaction on Turnover Intent: A Test of a Structural Measurement Model Using A National Sample of Workers.” Social Science Journal 38, no. 2 (2001): 233-250

Li, J. J., W. G. Kim, and X. R. Zhao "Multilevel Model of Management Support and Casino Employee Turnover Intention." Tourism Management 59, (2017): 193-204.

Liao, H., Chuang, A., and Joshi, A. "Perceived Deep-Level Dissimilarity: Personality Antecedents and Impact on Overall Job Attitude, Helping, Work Withdrawal, and Turnover." Organizational Behavior and Human Decision Processes 106, no. 2 (2008): 106-124.

Lin, C. P. and Liu, M. L. "Examining the Effects of Corporate Social Responsibility and Ethical Leadership on Turnover Intention.” Personnel Review 46, no.3 (2017): 526-550.

Loughlin, C. and Barling, J. Young “Worker's Work Values, Attitudes, And Behaviors.” Journal of Occupational and Organizational Psychology 74, no.4 (2001): 543-558

Lu, C. S. and Lin, C. C. "The Effects of Ethical Leadership and Ethical Climate on Employee Ethical Behavior in The International Port Context." Journal of Business Ethics 124, no.2 (2014): 209-223.

Mahsud, R., Yukl, G., and Prussia, G. "Leader Empathy, Ethical Leadership, And Relations-Oriented Behaviors as Antecedents of Leader-Member Exchange Quality." Journal of Managerial Psychology 25, no.6 (2010): 561-577.

Mayer, D. M., Aquino, K., Greenbaum, R. L., and Kuenzi, M. "Who Displays Ethical Leadership, And Why Does It Matter? An Examination of Antecedents and Consequences of Ethical Leadership." Academy of Management Journal 55, no.1 (2012): 151-171.

Mobley, W. H., Horner, S. O. and Hollingsworth, A. T. “An Evaluation of Precursors of Hospital Employee Turnover." Journal of Applied Psychology 63, no. 4 (1978): 408.

Morris, J. A., Brotheridge, G. M., and Urhanski, J. G. "Bringing Humility to Leadership: Antecedents and Consequences of Leader Humility." Human Relations 58, no.10 (2005): 1323-1350.

Mossholder, K. W., Settoon, R. P. and Henagan, S. C. "A Relational Perspective on Turnover: Examining Structural, Attitudinal, And Behavioral Predictors." Academy of Management Journal 48, no.4 (2005): 607-618. 
Nejati, M., Brown, M. E., Shafaei, A., and Seet, P. S. "Employees' Perceptions of Corporate Social Responsibility and Ethical Leadership: Are They Uniquely Related to Turnover Intention?" Social Responsibility Journal 17, no.2 (2020): 181-197.

Northouse, P. G. Leadership: Theory and Practice (7th ed.). (Thousand Oaks, CA: Sage, 2016).

Ochs, E. and Kremer-Sadlik, T. "Introduction: Morality as Family Practice.” Discourse \& Society 18, no.1 (2007): 5-10.

O'Connell, M. and Kung, M. C. "The Cost of Employee Turnover.” Industrial Management 49, no.1 (2007).

Ongori, H. "A Review of the Literature on Employee Turnover." African Journal of Business Management, (2007): 49-54.

O'Reilly, C., Chatman, J. and Caldwell, D. F. "People and Organizational Culture: A Profile Comparison Approach to Assessing Person-Organization Fit." Academy of Management Journal 34, (1991): 487-516.

Pitts, D., Marvel, J., and Fernandez, S. "So Hard to Say Goodbye? Turnover Intention Among US Federal Employees." Public Administration Review 71, (2011): 751-760.

Porter, L. W. and Steers, R. M. "Organizational, Work, and Personal Factors in Employee Turnover and Absenteeism." Psychological Bulletin 80, no.2 (1973): 151- 176.

Rappaport, J. "In Praise of Paradox: A Social Policy of Empowerment over Prevention." American Journal of Community Psychology 9, no.1 (1981): 1-2.

Ren, S., and Jackson, S. E. "HRM Institutional Entrepreneurship for Sustainable Business Organizations." Human Resource Management Review 30, no.3 (2020): 100691.

Rhodes, C. and Badham, R. "Ethical Irony and The Relational Leader: Grappling with the Infinity of Ethics and The Finitude of Practice." Business Ethics Quarterly 28, no. 1 (2018): 71 - 98

Rosch, P. J. "The Quandary of Job Stress Compensation.” Health and Stress 3, (2001): 1-4.

Saeed, I., Waseem, M., Sikander, S. and Rizwan, M. "The Relationship of Turnover Intention with Job Satisfaction, Job Performance, Leader Member Exchange, Emotional Intelligence and Organizational Commitment." International Journal of Learning and Development 4, no.2 (2014): 242-256.

Schminke, M., Ambrose, M. L. and Neubaum, D. O. "The Effect of Leader Moral Development on Ethical Climate and Employee Attitudes.” Organizational Behavior and Human Decision Processes 97, no.2 (2005): 135 151.

Schwepker Jr, C. H. "Ethical Climate's Relationship to Job Satisfaction, Organizational Commitment, And Turnover Intention in The Salesforce." Journal of Business Research 54, no.1 (2001): 39-52.

Shafique, I., N Kalyar, M. and Ahmad, B. "The Nexus of Ethical Leadership, Job Performance, And Turnover Intention: The Mediating Role of Job Satisfaction." Interdisciplinary Description of Complex Systems: INDECS 16, no.1 (2018): 71-87.

Shareef, R. A. and Atan, T. "The Influence of Ethical Leadership on Academic Employees' Organizational Citizenship Behavior and Turnover Intention: Mediating Role of Intrinsic Motivation." Management Decision 57, no.3 (2019): 583-605.

Sims, Randi L., and K. Galen Kroeck. "The influence of ethical fit on employee satisfaction, commitment and turnover." Journal of Business Ethics 13, no. 12 (1994): 939-947.

Staw, B. M. "The Consequences of Turnover." Journal of Occupational Behavior 1, (1980): 253-273.

Suifan, T. S., Diab, H., Alhyari, S. and Sweis, R. J. "Does Ethical Leadership Reduce Turnover Intention? The Mediating Effects of Psychological Empowerment and Organizational Identification." Journal of Human Behavior in the Social Environment 30, no.4 (2020): 410-428.

Tang, G., Cai, Z., Liu, Z., Zhu, H., Yang, X. and Li, J. “The Importance of Ethical Leadership in Employees' Value Congruence and Turnover." Cornell Hospitality Quarterly 56, no.4 (2015): 397-410.

Tett, R. P. and Meyer, J. P. "Job Satisfaction, Organizational Commitment, Turnover Intention, and Turnover: Path Analyses Based on Meta-Analytic Findings." Personnel Psychology 46, no.2 (1993): 259-293.

Treviño, L. K., Butterfield, K. and McCabe, D. "The Ethical Context in Organizations: Influences on Employee Attitudes and Behaviors." Business Ethics Quarterly 8, no.3 (1998): 447-476.

Walumbwa, F. O., Mayer, D. M., Wang, P., Wang, H., Workman, K. and Christensen, A. L. "Linking Ethical Leadership to Employee Performance: The Roles of Leader-Member Exchange, Self-Efficacy, And Organizational Identification." Organizational Behavior and Human Decision Processes 115, no. 2 (2011): 204-213.

Yin-Fah, B. C., Foon, Y. S., Chee-Leong, L. and Osman, S. “An Exploratory Study on Turnover Intention Among Private Sector Employees.” International Journal of Business and Management 5, no.8 (2010): 57.

Yukl, G., Mahsud, R., Hassan, S. and Prussia, G. E. "An Improved Measure of Ethical Leadership." Journal of Leadership \& Organizational Studies 20, no.1 (2013): 38-48.

Zhang, Z., Wang, M. and Shi, J. Q. "Leader-Follower Congruence in Proactive Personality and Work Outcomes: The Mediating Role of Leader-Member Exchange." Academy of Management Journal 55, no.1 (2012): 111-130. 